\title{
ПУБЛІЧНИЙ ІНТЕРЕС ТА ЛЕГІТИМНІ ОЧІКУВАННЯ ЯК СКЛАДНИКИ СУДОВОГО ЗАХИСТУ ПРАВА НА БЕЗПЕЧНЕ ДОВКІЛЛЯ
}

Шепель М. A.

у роботі на підставі аналізу міжнародних стандартів захисту права людини на безпечне та сприятливе довкілля обгрунтовано необхідність запровадження у національну правову систему України таких категорій, як «публічний інтерес» та «легітимні очікування». Автором виділено та здійснено змістову характеристику таких міжнародно-правових актів, як Декларація про навколишнє середовище (м. Стокгольм, 1972 р.), Декларація по навколишньому середовищу і розвитку (м. Ріо-де-Жанейро, 1992 р.), Конвенція $\mathrm{OOH}$ про доступ до інформаціі, участь громадськості у процесі прийняття рішень та доступ до правосуддя з питань, що стосуються довкілля (м. Орхус, 1997 р.). Автором здійснено огляд судової практики захисту права на безпечне довкілля, особливостей його розуміння у міжамериканській правовій системі порівняно із західноєвропейською правовою системою. До особливостей міжамериканської судової системи захисту права на безпечне довкілля віднесено функціонування механізмів захисту прав корінних народів на довкілля (що підтверджується рішенням Міжамериканської комісії з прав людини у справі “Maya Indigenous Communities of the Toledo District v. Belize"), договірний порядок урегулювання спорів у сфері захисту права на безпечне довкілля. Встановлено, що північноамериканське законодавство оперує поняттям «право на здорове довкілля», що належить до системи економічних, соціальних та культурних прав. Обгрунтовано, що принципи задоволення публічного інтересу та врахування легітимних очікувань учасників правовідносин визначають зміст трансформації відносин із захисту права на безпечне довкілля. Підкреслено, що запровадження принципу легітимних очікувань у начіональну судову систему захисту наданих особі прав та свобод вимагає перегляду розуміння предметної юрисдикції адміністративних судів України.

Ключові слова: довкілля, легітимні очікування, публічний інтерес, судовий захист, об'єкт, природні ресурси, суб'єкти, фізичні особи, юридичні особи.

В работе на основе анализа международных стандартов защиты прав человека на безопасную и благоприятную окружающую среду обоснована необходимость введения в национальную правовую систему Украины таких категорий, как «публичный интерес» и «легитимные ожидания». Автором выделена и осуществлена содержательная характеристика таких международно-правовых актов, как Декларация об окружающей среде (2. Стокгольм, 1972 г.), Декларация по окружающей среде и развитию (2. Рио-деЖанейро, 1992 г.), Конвенция ООН о доступе к информации, участии общественности в процессе принятия решений и доступе к правосудию по вопросам, касающимся окружающей среды (2. Орхус, 1997 г.). Автором осуществлён обзор судебной практики защиты права на безопасную окружающую среду, особенностей его понимания в межамериканской правовой системе по сравнению с западноевропейской правовой системой. $K$ особенностям межамериканской

Шепель М. А., 2019 судебной системы защиты права на безопасную окружающую среду отнесены функционирование механизмов защиты прав коренных народов на окружающую среду (что подтверждается решением Межамериканской комиссии по правам человека по делу "Maya Indigenous Communities of the Toledo District v. Belize"), договорный порядок урегулирования споров в сфере защиты права на безопасную окружающую среду. Установлено, что североамериканское законодательство оперирует понятием «право на здоровую окружающую среду», что относится к системе экономических, социальных и культурных прав. Обосновано, что принципы удовлетворения публичного интереса и учёта законных ожиданий участников правоотношений определяют содержание трансформации отношений по защите прав на безопасную окружающую среду. Подчёркнуто, что введение принципа легитимных ожиданий в национальную судебную систему защиты предоставленных лицу прав и свобод требует пересмотра понимания предметной юрисдикции административных судов Украины.

Ключевые слова: окружающая среда, легитимные ожидания, публичный интерес, судебная защита, объект, природные ресурсы, субъекты, физические лица, юридические лица.

Based on the analysis of international standards for protecting human rights to a safe and favorable environment, the study substantiates the need to introduce such categories as "public interest" and "legitimate expectations" into the national legal system of Ukraine. The author has identified and carried out a substantial characterization of such international legal acts as the Declaration on the Environment (Stockholm, 1972), the Declaration on the Environment and Development (Rio de Janeiro, 1992), Convention UN on access to information, public participation in decision-making and access to justice in environmental matters (Aarhus, 1997). The author reviewed the judicial practice of protecting the right to a safe environment, its understanding in the Inter-American legal system in comparison with the Western European legal system. The features of the Inter-American judicial system for protecting the right to a safe environment include the functioning of mechanisms for protecting the rights of indigenous peoples to the environment (as confirmed by the decision of the Inter-American Commission on Human Rights in the Maya Indigenous Communities of the Toledo District v. Belize case), the contractual procedure for the settlement of disputes in the field of protecting the right to a safe environment. It has been established that North American law operates with the concept of "the right to a healthy environment", which refers to the system of economic, cultural and social rights. It is proved that the principles of satisfying the public interest and taking into account the legitimate expectations of participants in legal relations determine the content of the transformation of relations to protect the rights to a safe environment. It is emphasized that the introduction of the principle of legitimate expectations in the national judicial system of protection of the rights and freedoms granted to a person requires 
reviewing the understanding of the subjective jurisdiction of the administrative courts of Ukraine.

Key words: environment, legitimate expectations, public interest, judicial protection, facility, natural resources, entities, individuals, legal entities.

Постановка проблеми та їі актуальність. Достеменно відомо, що природні ресурси $\epsilon$ своєрідним органічним капіталом будь-якої держави та їі стратегічним запасом, що визначає соціально-економічний потенціал держави. У сучасних умовах формування нового змісту економічних відносин в Україні постає необхідність не тільки перегляду пріоритетів у використанні окремих видів ресурсів, що склалися в минулому, формуванні нових способів їх використання та відтворювання, але й в удосконаленні правових механізмів забезпечення ефективності технологічних та виробничих процесів, у т. ч. і правових засобів захисту прав суб'єктів правовідносин, що виникають у цій сфері.

Одним із найбільш ефективних серед таких засобів захисту справедливо визнається судовий порядок оскарження. Проте наявність спеціального природоресурсного законодавства, низки процесуальних кодифікованих актів, розгалуженої системи судів в Україні не тільки не сприяє подоланню проблеми визначення юрисдикції спеціалізованих судів щодо розгляду та вирішення категорії справ, що $\epsilon$ предметом цього дослідження, а ще більше загострює іï. Однозначності у підходах щодо віднесення спорів, що виникають у сфері використання природних ресурсів, до того чи іншого виду судової юрисдикції ще і досі не вироблено ані на рівні законодавства, ані на рівні судової практики.

Ступінь розробленості проблеми. Слід підкреслити, що проблематика дотримання законності набуття спеціальних прав на використання природних ресурсів залишається актуальною і для сучасної юридичної науки, у т. ч. й адміністративно-правової. Необхідно виділити численні фундаментальні дослідження з питань використання природних ресурсів, що в різні часи проводилися такими вченими, як В.І. Андрейцев, А.П. Гетьман, Р.С. Кірін, Н Р. Кобецька, Ю.О. Легеза, П.М. Рабінович, Ю.С. Шемшученко та ін.

Питання визначення юрисдикції розгляду спорів з приводу використання природних ресурсів зводяться, як правило, до встановлення особливостей визначення юрисдикції у розгляді земельних спорів, що знайшло відображення у дослідженнях В.М. Бевзенка, В.В. Квака, Н.В. Коваленко, П.М. Мельника, М.І. Смоковича, В.П. Тимощука та ін.

Загальні аспекти адміністративно-правового регулювання публічного управління в різних сферах і галузях, включаючи використання природних ресурсів, були предметом досліджень багатьох вітчизняних адміністративістів, зокрема: В.Б. Авер'янова, О.Ф. Андрійко, К.К. Афанасьєва, О.М. Бандурки, В.М. Бевзенка, Ю.П. Битяка, Л.Р. Білої-Тіунової, М.Ю. Віхляєва, В.М. Гаращука, Є.А. Гетьмана, І.П. Голосніченка, І.С. Гриценка, Н.Л. Губерської, Є.В. Додіна, Т.Є. Кагановської, Р.А. Калюжного, С.В. Ківалова, Л.П. Коваленко, І.Б. Коліушка, Т.О. Коломоєць, В.К. Колпакова, А.Т. Комзюка, О.В. Константого, С.В. Кувакіна, С.О. Кузніченка, О.В. Кузьменко, Є.В. Курінного, М.В. Лошицького, Д.М. Лук'янця, П.С. Лютікова, Р.С. Мельника, О.І. Миколенка, О.М. Музичука, Н.Р. Нижник, С.Г. Сте- ценка та ін. Проте в наш час відсутні праці, в яких би комплексно аналізувались проблеми розгляду публічно-правових спорів у сфері захисту права на безпечне довкілля урсів у порядку адміністративного судочинства.

Таким чином, необхідність забезпечення раціонального використання природних ресурсів в Україні, визначення шляхів реалізації права виключної власності Українського народу на природні ресурси та відсутність правового регулювання визначення критеріїв розмежування судової юрисдикції зумовлюють актуальність проведення наукового дослідження, присвяченого вирішенню дискусійних питань з приводу вирішення проблем розгляду публічно-правових спорів у сфері використання природних ресурсів у порядку адміністративного судочинства.

Метою дослідження $\epsilon$ визначення сутності розуміння публічного інтересу та легітимних очікувань як складників права на судовий захист загалом і у сфері охорони довкілля зокрема.

Виклад основного матеріалу. Уперше міжнародно-правове закріплення права людини на сприятливе довкілля було здійснено під час конференції Організації Об'єднаних Націй у 1972 році у Стокгольмі, внаслідок діяльності якої було ухвалено Декларацію про навколишнє середовище [1]. Декларація про навколишнє середовище $\epsilon$ першим міжнародно-правовим документом, де зроблено акцент на доцільності запровадження обов'язку держав, що їі ратифікували, не лише забезпечувати безпеку довкілля, але і створювати умови для його сприятливості.

Наступним міжнародно-правовим документом, що було присвячений встановленню стандартів захисту довкілля, $є$ Декларація по навколишньому середовищу і розвитку, прийнята у 1992 році на Конференції ООН у Ріо-де-Жанейро [2], де зроблено акцент на доцільності створення дієвих механізмів доступу до екологічної інформації, доступу до здійснення публічного управління у сфері захисту довкілля, доступу до правосуддя у досліджуваній галузі.

Справедливо одним із фундаментальних нормативно-правових актів, присвячених захисту довкілля, $\epsilon$ Орхуська конвенція ООН - «Конвенція ООН про доступ до інформації, участь громадськості у процесі прийняття рішень та доступ до правосуддя з питань, що стосуються довкілля» 1998 року, що була ратифікована Верховною Радою Україні 6 липня 1999 року [3].

Певні особливості захисту права на безпечне довкілля має міжамериканська правова система порівняно із західноєвропейською моделлю. До таких особливостей варто віднести створення механізмів захисту прав корінних народів на довкілля (що підтверджується рішенням Міжамериканської комісії з прав людини у справі “Maya Indigenous Communities of the Toledo District v. Belize”) [4], договірний порядок врегулювання спорів у сфері захисту права на безпечне довкілля. Північноамериканське законодавство оперує поняттям «право на здорове довкілля», що належить до системи економічних, соціальних та культурних прав [5, с. 180].

До стандартів застосування механізмів захисту права людини на сприятливе «здорове» довкілля, що $є$ загальновживаними в США, необхідно віднести висновок, ухвалений Міжамериканською комісією з прав людини у справах “Mary and Carrie Dann v. United States" 2002 p. [6], "Maya Indigenous Communities of the Toledo District 
v. Belize" 2004 p. [7] щодо неприйнятності аргументації держав-відповідачів про те, що певні справи мають розглядатися виключно в межах природоресурсних відносин без їх кореляції із визначенням критеріїв ефективності забезпечення реалізації прав та свобод людини, в тому числі права людини на життя та здоров'я.

Цікавими $\epsilon$ підходи, що застосовуються під час врегулювання права корінних народів у їх володінні, користуванні чи розпорядженні землею, що визначає їх походження. Так, у справах Інуїтів проти США та Атабасків проти Канади визначено, що для корінних народів відносини права власності на землює не лише товарно-виробничими, а і духовно-культурними відносинами, заподіяння шкоди яким безпосередньо впливає на їхнє право на честь, гідність та національну ідентифікацію [8].

Варто відзначити для міжамериканської системи розгляду та вирішення адміністративно-правових спорів у сфері захисту довкілля і результати практики Європейського суду з прав людини. Зокрема, Європейський Суд з прав людини тлумачить положення Декларації по навколишньому середовищу і розвитку, прийнятої у 1992 році на Конференції ООН у Ріо-де-Жанейро [2], як право корінних народів на встановлення обов'язку держав на забезпечення їх доступу до природних ресурсів місцевості, 3 якою пов'язується їх походження. Вирішення питання користування такими природними ресурсами чи об'єктами має виходити не лише з аргументації економічної доцільності, але і здійснення оцінки проєктів землеустрою у їх взаємозв'язку із реалізацією їхнього права на національну ідентифікацію. Крім того, у разі прийняття управлінських рішень у сфері використання природних об'єктів уряд має здійснювати консультування з племінними народами щодо вирішення питання визначення правового титулу відповідних земель національної ідентифікації (зокрема, таке тлумачення прав корінних народів здійснено у справах Saramaka People v. Suriname 2007 p., Kichwa Indigenous People of Sarayaku v. Ecuador 2012 р.) [9, п. 129, 133-134, 138; 10, п. 159, 177-211].

Необхідно підкреслити, що для міжамериканської системи захисту прав і свобод людини загалом і у сфері охорони довкілля зокрема притаманне еволютивне тлумачення положень національних та міжнародних нормативних актів. Зокрема, у справі Mayagna (Sumo) Awas Tingni Community v. Nicaragua 2001 р. Міжамериканський суд з прав людини, попри відсутність безпосереднього встановлення механізмів захисту прав племінних народів у Американській конвенції щодо права на власність, визначив, що порушення права власності таких суб'єктів на використання земельних ресурсів, що пов'язується зі збереженням традиції племінного способу життя, $\epsilon$ порушенням права людини на життя та здоров'я, права людини на приватне та особисте життя, а тому захищаються положеннями ст. 21 Американської конвенції [11].

Відповідно до міжнародних стандартів, зокрема міжамериканських стандартів захисту права на безпечне довкілля, встановлюється принцип транскордонної юрисдикції, що передбачає можливість застосування заходів публічної відповідальності до країни, що межує із територією країни, де заподіяно шкоду, якщо шкода виникла внаслідок порушення стандартів екологічної безпеки сусідньою державою, в тому числі в умовах військової агресії (окупації) (advisory
Opinion OC-23/17 on Environment and Human Rights of 15 November 2017) [12].

3 урахуванням зазначених вище особливостей судового захисту права на сприятливе довкілля і права людини на життя та здоров'я, як пов'язаного із ним, необхідно відзначити їх унікальність. Унікальність міжамериканської системи полягає у функціонування квазісудового органу контролю - Міжамериканської комісії з прав людини, що є уповноваженим суб'єктом на розгляд такої категорії публічно-правових спорів. При цьому, попри відсутність вказівки на імперативність правозастосування висновків Міжамериканської комісії з прав людини, на практиці її положення використовуються судовими інстанціями під час розгляду та вирішення спорів у сфері захисту права на безпечне довкілля. Встановлений Міжамериканською комісією з прав людини принцип транскордонної відповідальності за заподіяння екологічної шкоди може бути використано Україною у світлі необхідності вирішення проблеми компенсації екологічної шкоди, заподіяної внаслідок окупації територій Донецької та Луганської областей, що корелюється із положеннями Протоколу № 16 до Конвенції про захист прав людини [13].

Європейська та світова судова практика свідчить про зазначену тенденцію щодо встановлення дієвих механізмів захисту не лише визначених чинним законодавством прав, але і такої відносно нової категорії, як «легітимні очікування».

Запровадження у правову систему України категорії «легітимні очікування» насамперед пов'язується із практикою ЄСПЛ, що із прийняттям Закону України «Про виконання рішень та застосування практики Європейського суду з прав людини» від 23 лютого 2006 року № 3477-IV [14], що визначило механізм реалізації українською державою покладених на неї зобов'язань, які виникають у зв'язку із невиконанням чи неналежним забезпеченням реалізації прав і свобод. Принцип необхідності врахування легітимних очікувань $\epsilon$ похідним від принципу правової визначеності, відповідає реалізації інших принципів, таких як добросовісність, правова визначеність, належне урядування, пропорційність, передбачуваність тощо.

Створення дієвих механізмів реалізації таких європейських та світових принципів $\epsilon$ гарантією дотримання прав і свобод людини під час розгляду та вирішення спорів в Україні.

Розуміння такої категорії, як «легітимні очікування», $\epsilon$ необхідним в аспекті здійснення оцінки ефективності діяльності органів публічного управління в Україні.

Реалізація принципу легітимних очікувань в аспекті створення сприятливого та безпечного довкілля набуває особливого значення з урахуванням того, що природні ресурси («земля, іï надра, атмосферне повітря, водні та інші природні ресурси, які знаходяться в межах території України») та низка природних об'єктів (об'єкти природо-заповідного фонду, територіальне море та низка інших особливо охоронюваних об'єктів) (ст. 13 Конституції України; ст. 1 Закону України «Про природно-заповідний фонд») мають характер публічного блага, їх використання має підвищений публічний інтерес і вимагає створення спеціальних режимів забезпечення раціональності природокористування (поєднання економічного прибутку i «екологізації» виробництва як складника концепції сталого розвитку [15]). 
Особливого значення тому набуває питання досягнення справедливого балансу між приватними та публічними інтересами. Варто відзначити, що актуальна проблема задоволення публічного інтересу насамперед пов'язувалась із його реалізацією у сфері адміністративно-екологічних правовідносин.

Варто відзначити, що вже починаючи з 80-х років минулого століття виокремлюється стійка тенденція визначення механізмів захисту та реалізації публічного інтересу. Так, у Федеративній Республіці Німеччина під час вирішення еколого-правових спорів адміністративні суди як аргументацію прийняття рішення визначали необхідність задоволення «публічного інтересу» як базису природозахисних відносин. При цьому, за словами дослідників, німецькі суди й законодавча влада стикалися зі значним політичним тиском, щоб здійснювати законні реформи, які б давали змогу захищати публічні інтереси в екологічній сфері [16, с. 198]. У межах німецького адміністративного права під «публічним інтересом» розуміється «природний інтерес особистості», пріоритетність якого для більшості суспільства об'єктивізувалася і відповідним чином легалізувалась [17, с. 100]. Тобто в такому сенсі правові норми, спрямовані на реалізацію публічного інтересу, водночас сприяють реалізації інтересу окремої особи. Реалізація публічного інтересу вимагає встановлення не лише відповідальності громадськості, але і органів публічної адміністрації [17, с. 100].

Варто відзначити, що в межах німецького адміністративного права публічний інтерес належить до категорії «генеральної клаузули», тобто норми, що застосовується у вигляді загального недиференційованого поняття, що створює можливості для застосування адміністративного розсуду під час прийняття управлінських рішень. У такому розумінні застосування категорії «публічний інтерес» вимагає наявності високого рівня правової культури службових осіб суб'єктів публічного управління, передбачає необхідний рівень розуміння сукупності наявних обставин справи, в умовах існування якої $є$ доцільною така категорія [18].

Таке розуміння категорії «публічний інтерес» покладено в основу законодавства низки інших зарубіжних країн. Зокрема, відповідно до законодавства Республіки Польща розуміється категорія «публічний інтерес», що не вимагає законодавчого визначення переліку іï складників, іï застосування вимагає розуміння наявних обставин справи. Так, відповідно до підходу, запропонованого польським ученим М. Вижиковським, надання категорії «публічний інтерес» категорії «генеральної клаузули», що дозволяє застосовувати розсудний характер змісту публічного інтересу, водночас зовсім не означає його довільності. Для цього, вважає науковець, підлягають нормативному трактуванню якщо й не всі характеристики публічного інтересу (що $€$ неможливим), то хоча 6 його сутність як суспільної цінності та визначальні його межі, які не можна порушувати в конкретних суспільних та державних умовах [19].

Попри наявний підхід допустимості застосування адміністративного розсуду під час визначення розуміння «публічного інтересу» у польському законодавстві $\epsilon$ низка нормативно-правових актів, де у певних сферах така категорія деталізується. Зокрема, такими $\epsilon$ закон про просторове планування й господарювання; про банківське право; про нагляд за фінансовим ринком [20, с. 167].

Висновки. Принципи задоволення публічного інтересу та врахування легітимних очікувань учасників правовідносин визначають зміст трансформації відносин із захисту права на безпечне довкілля. Застосування таких принципів $\epsilon$ безумовним складником забезпечення ефективності реалізації вимог із встановлення верховенства права як головного регулятора суспільних відносин. Принципи задоволення публічного інтересу та врахування легітимних очікувань мають бути визначені як пріоритетні засади розбудови ефективної системи захисту довкілля, створення умов для сприятливого розвитку людини в умовах необхідності забезпечення екологізації процесів виробництва. Принципи задоволення публічного інтересу та врахування легітимних очікувань мають застосовуватися із поєднанням таких загальновизнаних принципів, як принципи належного урядування, пропорційності, добросовісності, стабільності правового регулювання, передбачуваності, усунення конфлікту інтересів, принцип недопущення суперечливої поведінки тощо. Водночас запровадження принципу легітимних очікувань у національну судову систему захисту наданих особі прав та свобод вимагає перегляду розуміння предметної юрисдикції адміністративних судів України.

\section{Література}

1. Декларация Конференции ООН по проблемам окружающей человека среды : международный документ от 16 июня 1972 г. URL: https://zakon.rada.gov.ua/laws/ show/995_454 (дата звернення: 15.09.2019).

2. Декларація Ріо-де-Жанейро щодо навколишнього середовища та розвитку : міжнародний документ від 14 червня 1992 р. / Верховна Рада України. URL: https://zakon.rada.gov.ua/laws/show/995_455 (дата звернення: 15.09.2019).

3. Конвенція про доступ до інформації, участь громадськості в процесі прийняття рішень та доступ до правосуддя з питань, що стосуються довкілля (Орхуська конвенція) : міжнародний документ ООН від 25 червня 1998 р. (ратифікований Законом України від 6 липня 1999 р. № 832-XIV) / Верховна Рада України. Офіційний вісник України. 2010. № 33. С. 12. Ст. 1191.

4. Maya Indigenous Communities of the Toledo District v. Belize. URL: http://www.worldcourts.com/iacmhr/eng/ decisions/2000.10.05_Maya_Indigenous_Communities_v_ Belize.pdf (дата звернення: 15.09.2019).

5. Медведєва М. Міжамериканська система захисту права на безпечне довкілля. Міжнародний судовий форум «Судовий захист природного довкілля та екологічних прав» (М. Київ, 7 листопада 2019 року) : Збірник матеріалів. Київ, 2019. С. 178-183.

6. Mary and Carrie Dann v. United States, Case 11.140, Report No. 75/02, Inter-Am. C.H.R., Doc. 5 rev. 1 at 860 (2002). URL: http://hrlibrary.umn.edu/cases/75-02a.html (дата звернення: 15.09.2019).

7. Maya Indigenous Communities of the Toledo District v. Belize. URL: http://www.worldcourts.com/iacmhr/eng/ decisions/2000.10.05_Maya_Indigenous_Communities_v_ Belize.pdf (дата звернення: 15.09.2019).

8. Case of Mayagna (Sumo) Awas Tingni Community v. Nicaragua : Judgment of the Inter-American Court of human rights of 31 August 2001. URL: http://www.corteidh.or.cr/ docs/casos/articulos/seriec_79_ing.pdf (дата звернення: 15.09.2019). 


\section{адміністративної реформи}

9. Case of the Saramaka People v. Suriname : Judgment of the Inter-American Court of human rights of 28 November 2006. URL: http://www.corteidh.or.cr/docs/casos/articulos/ seriec_172_ing.pdf (дата звернення: 15.09.2019).

10. Case of the Kichwa Indigenous People of Sarayaku v. Ecuador : Judgment of the InterAmerican Court of human rights of 27 June 2012. URL: http://corteidh.or.cr/ docs/ casos/articulos/seriec_245_ing.pdf (дата звернення: 15.09.2019).

11. Case of the Yakye Axa Indigenous Community v. Paraguay : Judgment of the InterAmerican Court of human rights of 17 June 2005. URL: http://www.corteidh.or.cr/ docs/casos/articulos/seriec_125_ing.pdf (дата звернення: 15.09.2019).

12. Advisory Opinion OC- $23 / 17$ on Environment and Human Rights of 15 November 2017 / Inter-American Court of Human Rights. URL: http://www.corteidh.or.cr/docs/ opiniones/seriea_23_esp.pdf (дата звернення: 15.09.2019).

13. Протокол № 16 до Конвенції про захист прав людини і основоположних свобод від 02.10.2013 року. URL: https://zakon.rada.gov.ua/laws/show/994_002-13 (дата звернення: 15.09.2019).

14. Про виконання рішень та застосування практики Європейського суду з прав людини : Закон України від 23 лютого 2006 року № 3477-IV. Відомості Верховної Ради України. 2006. № 30. Ст. 260.

15. Резолюція Генеральної Асамблеї ООН № $70 / 1$ від 25 вересня 2015 року «Перетворення нашого світу. Порядок денний у сфері сталого розвитку на період до 2030 року». URL: http://sdg.org.ua/ua/resources-2/344-2030-2015 (дата звернення: 15.09.2019).

16. Greve M.S. The Non-Reformation of Administrative Law: Standing to Sueand Public Interest Litigation in West German Environmental Law. Cornell International Law Journal. 1989. Vol. 22. P. 197-244.

17. Шерстобоев О.Н. Теория интересов в административно-правовом измерении. Российский юридический журнал. 2014. № 3. С. 99-108.

18. Rekosh E. Who defines the public interest? Public interest law strategies in Central and Eastern Europe. URL: http: / / www.scielo.br/scielo.php?pid=\$1806-6445200 5000100008\&script=sci_arttext\&tlng=en (дата звернення: 15.09.2019).

19. Weintraub J. Varieties and Vicissitudes of Public Space. Metropolis: Center and Symbol of Our Times / ed.by Ph. Kasinitz. New York : New York University Press, Forthcoming, 1995. P. 13-31.

20. Komierzynska E., Zdyb M. Klauzula interesu publicznego w dzialaniach administracji publicznej. Annales Universitatis Mariae Curie-Sklodowska. 2016. Vol. LXIII, 2. S. 161-179.

Шепель М. A., здобувач кафедри адміністративного та господарського права Запорізького національного університету 